\&.Edu.\&Sci. , The first conference on Biology, (September-2007)

\title{
The Use of RAPDs Technique for the Detection of Genetic Stability of Date Palm Plantlets Derived From In Vitro Culture of Inflorescence
}

Saleh M. Bader ${ }^{(1)}$, Michael Baum ${ }^{(2)}$, Hussam. S. M. Khierallah ${ }^{(3)}$, \& Wafaa Choumane ${ }^{(4)}$

(1) State Board of Agricultural Researches, Ministry of Agriculture, Baghdad-Iraq.

(2) The international center for Agricultural research in the Dry Areas (ICARDA), Aleppo, Syria

${ }^{(3)}$ Horticulture Dep., College of Agriculture, University of DiyalaIraq

${ }^{(4)}$ Faculty of Agriculture, Tishreen University, Lattakia,Syria.

\section{الخلاصة}

(RAPD) DNA استخدمت تقانة مؤشر ات التضاعف العشو ائي المتعدد الأشكال لسلسلة

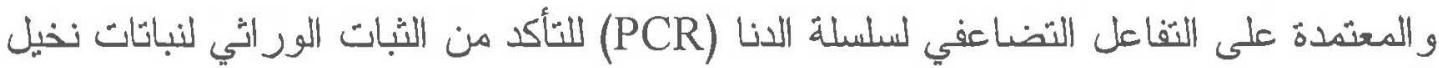

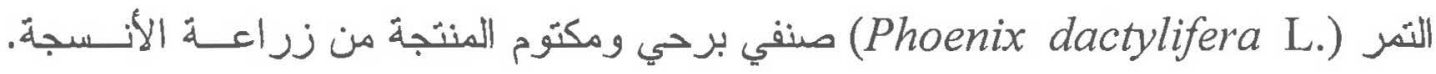

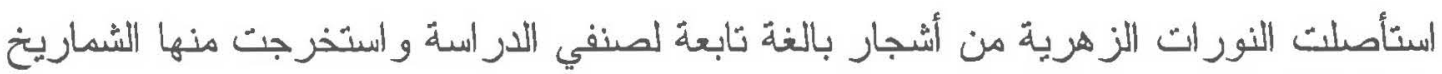
وقسمت الى قطع صغيرة بطول 0.5 سم وزرعت في وسط MS الدحور المجزز بـــ 100 مايكرومول من 2,4-D و 15 مايكرومول من 2ip. تم الحصول على نسيج الكالس بعـد 8

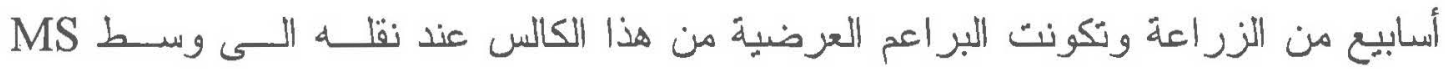

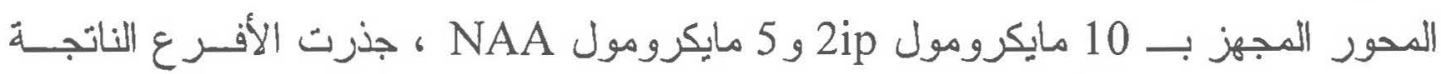

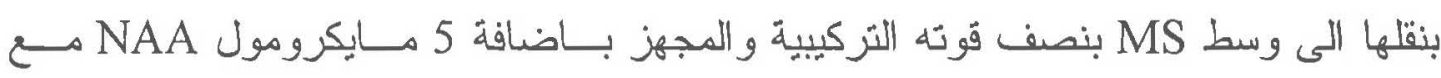

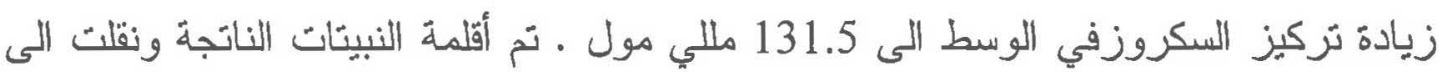

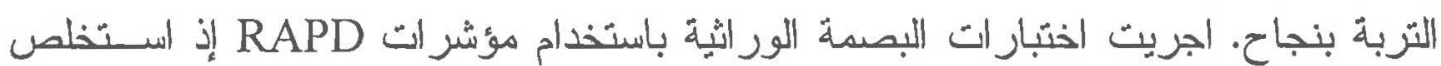

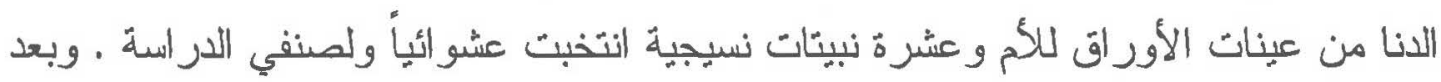
تحديد الظروف المثلى لنفاعلات RAPD تم الحصول على نتائج و اضحة ومنعددة لأنمساط

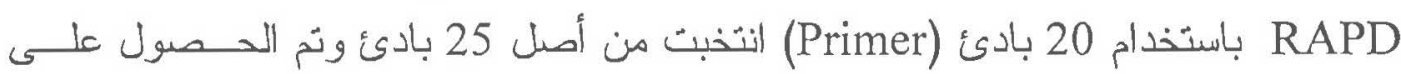

- Presented at the first conference on Biology, University of Mosul ,college of Education, 4-5 September 2007 


\title{
The Use of RAPDs Technique for....
}

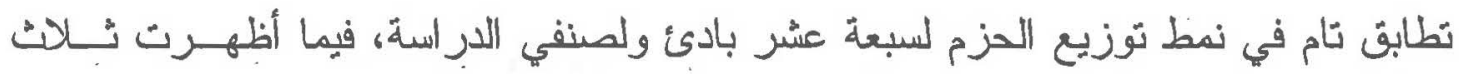

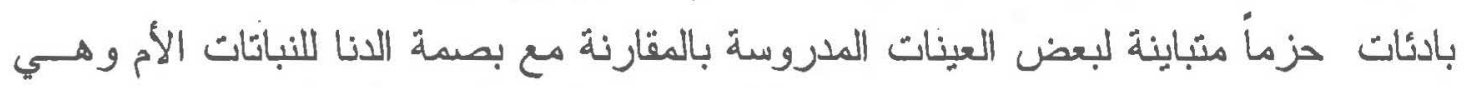

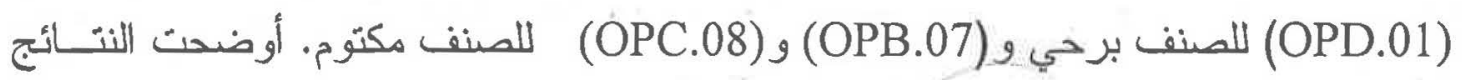

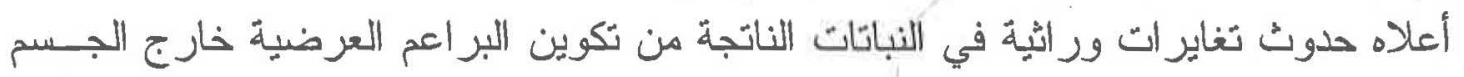

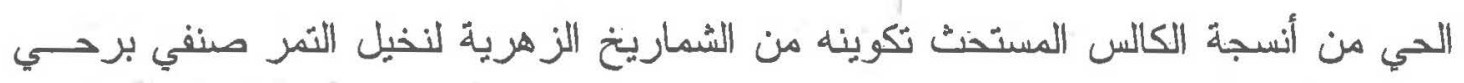

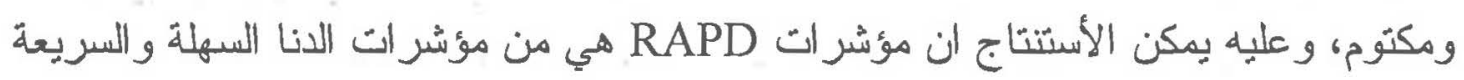

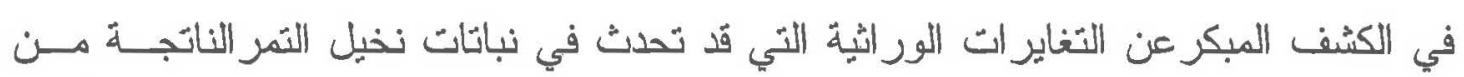
زر اعة الأنسجة النباتية.

\begin{abstract}
The study aimed to use of RAPD - PCR markers to prove the genetic stability of two date palm (Phoenix dactylifera L.) cultivars Barhi and Maktoom produced by tissue culture technique. Inflorescences were excited from adult tree of the two cultivars. Spadixes were divided in to pieces $0.5 \mathrm{~cm}$ in length and cultured on MS modified medium supplemented with $100 \mu \mathrm{M}$ of 2,4-D and $15 \mu \mathrm{M}$ of 2ip. Callus was obtained after 8 weeks and adventitious shoots formation was achieved when callus transferred to MS modified medium supplemented with 10 $\mu \mathrm{M}$ of $2 \mathrm{ip}$ and $5 \mu \mathrm{M}$ of NAA. Shoots rooted on half strength MS salts medium supplemented with $5 \mu \mathrm{M}$ of NAA with increasing sucrose concentration to $131.5 \mathrm{mM}$. Plantlets were acclimatized and successfully transferred to soil. RAPD - PCR analysis using 25 universal primers were performed on DNA extracted from the fresh healthy leaves of the mother tree and from samples randomly taken plantlets derived from tissue culture. Reproducible RAPD patterns were obtained using 20 primers, Seventeen primers showed completely monomorphic bands in all samples tested of the progeny. Only three primers showed some polymorphic bands on the agarose gel for both cultivars in some samples tested comparing with the DNA banding pattern for the intact trees, these were OPD.01 primer for Barhi, and OPB.07 and OPC.08 for Maktom. According to the results above it was obvious that genetic variations could occurred in plantlets derived from callus proliferated from inflorescence of date palm, furthermore RAPD appears to be an efficient technique and a simple fast DNA marker for the early detection of genetic variations in plants propagated by tissue culture technique.
\end{abstract}




\section{INTRODUCTION}

Date palm Phoenix dactylifera L., $(2 \mathrm{n}=2 \mathrm{x}=36)$ are dioecious, perennial, monocotyledon fruit trees that belong to the family of Arecaceae (1). Dates is the major fruit crop of arid climate region in countries of Middle East and North Africa.

The heterozygousty of date palm makes its progeny strongly heterogeneous (2). Thus the propagation of date palm through offshoots is preferred over the seedlings. Since propagation through offshoots is slow and affected by their low survival rate, tissue culture of female plants has been preferred widely for mass production of true-to-type plants of elite varieties in demand. Propagation by either offshoots or tissue culture generally results in true-to-type plants but some off-types with abnormal phenotypes also develop in tissue cultured plants which may be due to Somaclonal Variations (3).

The use of plant tissue culture techniques through direct or indirect organogenesis by using inflorescences as explants was mentioned by several researchers $(4,5,6)$. Although successful results were reported, no evolution strategies have been used at early stage to assess the uniformity of their tissue-cultured trees. Since long lived plants may have mutants even in apical meristem (7) and during the last few years, variations have been detected among in vitro date palm plants (Barhi, Medjool and Khalas) such as Dwarfism, delay in fruiting and fruiting set failure $(8, \underline{9}$ ,10,11). All these cases would greatly affect the utilization of tissue culture techniques. Various techniques were used to confirm the true to typeness produced in vitro. The morphological markers are based on features like leaf shape, pinnae, fruit stalk and fruit characteristics $(12,3)$ : Detection of genetic stability based on morphological markers is difficult. Identification of trees is not usually possible until the onset of fruit, which takes at least five years. Furthermore, a large set of phenotypic data are required that are difficult to assess statistically and are variable due to environmental effects (13). Biochemical markers (isozymes and proteins) have proved to be effective in varietal identification of date palm $(14,15)$. However, they give limited information and are an indirect approach for detecting genomic variation. In recent years and among the different techniques used in generating molecular markers, for direct detection of genomic variation at DNA level, Random Amplified Polymorphic DNA (RAPD) markers have been successfully used for the cultivar analysis and species identification in most plants, due to the technical simplicity and speed of the methodology $(16,17,18)$. The objective of the present study was to employ PCR-RAPD markers for the early detection of genetic variations in date palm inflorescence in vitro culture-derived plants. 


\section{MATERIALS AND METHODS}

\section{Plant material and tissue culture}

Floral spathes with immature inflorescences were excised from adult trees of the two cultivars Barhi and Maktom in early spring. Spathes were surface sterilized with $0.1 \%$ mercuric chloride $\left(\mathrm{HgCl}_{2}\right)$ for 10 min under aseptic conditions, rinsed three times with sterile distilled water and transferred to sterile petri dishes. Spikes were excised and divided into $0.5 \mathrm{~cm}$ segments. Explants excised from spathes (8-10) $\mathrm{cm}$ with spikes of (3-5) $\mathrm{cm}$ in length were cultured on Murashige and Skoog (MS) (19) modified medium supplemented with the following in ( $\mathrm{mg} / \mathrm{l})$ : thiamine$\mathrm{HCl}, 1.0$; pyridoxine - $\mathrm{HCl}, 1.0$; Nicotinic acid 1.0; Glycine, 2.0; adenine sulfate, 40; myo-inositol, 100; $\mathrm{NaH}_{2} \mathrm{PO}_{4} \cdot 2 \mathrm{H}_{2} \mathrm{O}, 170$; glutamine, 100 ; sucrose, 30000; activated charcoal , 2000 and agar-agar 7000 containing $100 \mu \mathrm{M} 2,4-\mathrm{D}$ plus $15.0 \mu \mathrm{M} 2 \mathrm{iP}$ for callus induction. The $\mathrm{pH}$ of the medium was adjusted to 5.7 with $0.1 \mathrm{~N} \mathrm{NaOH}$ or $\mathrm{HCl}$, before the addition of agar. The media were dispensed into culture test tubes with $25 \mathrm{ml}$ in each one, and then covered with polypropylene caps. All vials with media were autoclaved under $1.04 \mathrm{~kg} / \mathrm{cm}^{2}$ of $121{ }^{\circ} \mathrm{C}$ for 15 minutes. Adventitious shoots were obtained when callus was transferred to MS liquid agitated medium supplemented with $10.0 \mu \mathrm{M} 2 \mathrm{iP}$ and $5.0 \mu \mathrm{M}$ NAA. Adventitious shoots were elongated, rooted, acclimatized and successfully transplanted in the soil under glasshouse conditions.

\section{DNA extraction}

Total cellular DNA was extracted according to the standard procedure (20) with some modifications. About $0.1 \mathrm{~g}$ fresh and healthy leaves of the intact trees and from ten samples randomly selected plantlets derived from tissue culture, were grounded to a fine powder using liquid nitrogen. Five milliliters of hot $\left(60^{\circ} \mathrm{C}\right) 2 \mathrm{X} \mathrm{CTAB}$ extraction buffer $(2 \% \mathrm{CTAB}, 1.4$ $\mathrm{M} \mathrm{NaCl}, 0.1 \mathrm{M}$ Tris- $\mathrm{HCl} \mathrm{pH} 8,20 \mathrm{mM}$ EDTA and $0.2 \% \quad \beta-$ mecaptoethanol) were added, mixed well, and incubated at $60^{\circ} \mathrm{C}$ in a water bath. After $60 \mathrm{~min}$ of incubation at $60^{\circ} \mathrm{C}$ with gentle swirling, the resulting cell was lysed and extracted with an equal volume of chloroform/isoamyl alcohol $(24: 1 \mathrm{v} / \mathrm{v})$. The cell lysate was then centrifuged $\left(4000 \mathrm{~g}, 20^{\circ} \mathrm{C}, 15 \mathrm{~min}\right)$. The aqueous phase was transferred into another tube where precipitation occurred by the addition of 0.66 volume of isopropanol. The precipitate was then collected by centrifugation $\left(10000 \mathrm{~g}, 20^{\circ} \mathrm{C}, 10 \mathrm{~min}\right)$. Pellets were washed with $70 \%$ ethanol, dried and dissolved overnight at $4{ }^{\circ} \mathrm{C}$ in $1 \mathrm{ml}$ of TE buffer $(10$ $\mathrm{mM}$ Tris - $\mathrm{HCl} \mathrm{pH} 8.0,1 \mathrm{mM}$ EDTA). After purification, the resultant DNA was quantified and its integrity was determined after agarose gel electrophoresis as previously described (21) 


\section{RAPD analysis}

RAPD analysis was carried out by following the described method (22) with few modifications. A total of 25 random decamer primers (Operon Technologies Inc., Alameda, California, USA) were used for RAPD amplification. PCR reactions were carried out in $25 \mu \mathrm{l}$ volume containing $25 \mathrm{ng}$ of total genomic DNA from each sample for both cultivars, $0.2 \mu \mathrm{l}$ of a single primer, $100 \mathrm{mM}$ of each dNTPs, 1X PCR buffer (10 mM Tris- $\mathrm{HCl} \mathrm{pH} \mathrm{8.3,} 50 \mathrm{mM} \mathrm{KCl}, 2 \mathrm{mM} \mathrm{MgCl}$ ) and 1 unit DNA Taq polymerase (23). Amplification was performed in a thermocycler (PE 9600) programmed for RAPD: 1 cycle at $94^{\circ} \mathrm{C}$ for 4 min, and 35 cycles with the following cycle profile: 1 min DNA denaturation step at $94^{\circ} \mathrm{C}, 2$ min annealing step at $36^{\circ} \mathrm{C}, 2$ min extension step at $72{ }^{\circ} \mathrm{C}$ and last cycle at $72{ }^{\circ} \mathrm{C}$ for $7 \mathrm{~min}$, and an optional soak period at $4{ }^{\circ} \mathrm{C}$. Amplification products were loaded on $1 \%$ agarose gel and stained with ethidium bromide $(0.5 \mathrm{mg} / \mathrm{ml})$. Amplification for each primer was performed at least twice and only reproducible products were taken. DNA was visualized on a UV transilluminators and photographed using Polaroid black and white film (667-type). Fragments lengths were estimated by comparison with standard size markers (Lambda fage DNA digested with Hind III and Eco R1).

\section{RESULTS AND DISCUSION}

\section{Micropropagation}

Callus formation on floral explants was achieved after 12 weeks of incubation in the dark (Fig 1.a). The best response percentage to callus formation was $40 \%$ and $70 \%$ for Barhi and Maktom respectively. Adventitious buds formed on callus occurred after another 12 weeks (Fig 1.b,c,d). Results indicated that $80 \%$ of the cultures contain 11.2 and 24.8 buds for the two cultivars respectively was achieved using liquid agitated medium supplemented with $10.0 \mu \mathrm{M}$ 2ip and 5.0 $\mu \mathrm{M}$ NAA. Shoots produced were rooted after transferred on $5.0 \mu \mathrm{M}$ NAA and $131.5 \mathrm{mM}$ sucrose added to half-strength MS salts (Fig 1.e). Plantlets were acclimatized and successfully transferred to soil (Fig 1.f).

\section{Genetic Stability of Tissue Culture-Derived Plants}

A preliminary experiment was conducted to generate RAPD pattern with 25 primers to identify those that would be suitable in the present study to ensure reproducibility of RAPD marker data, the primers generating no or faint (nonreproducible) bands were discarded (OPA.01, OPB.03, OPC.03, OPD.09 and OPF.05) (Table 1). Twenty primers showed clear and good amplification results. Most of them, about 17, generated monomorphic banding pattern for all samples tested for both 
cultivars (Fig.2 a), while three of the twenty primers showed polymorphic banding pattern. These primers were: OPD.01 for Barhi and OPB.07, OPC.08 for Maktom, as shown in Fig. 2(b,c,d). The number of amplified fragments generated by these primers varied from 8 (OPB.7) to 12 (OPD.1) with an average of 10 bands for each sample. Molecular weight scored band range from $0.2 \mathrm{~kb}$ to $4900 \mathrm{~kb}$.

Polymorphisms were detected by presence or absence and of molecular weight of amplified fragments for each primer used. As shown in Fig. 2 (b,c,d) that there are genetic changes in the DNA amplification pattern by using OPB. 7 and OPC. 8 primers for sample 4 of Maktom cultivar when compared to the intact tree and other tested plantlets. DNA amplification pattern for sample 9 of Barhi cultivar showed genetic changes by using OPD.01 primer. Table 2 summarized the genetic variation reveled by RAPD markers.

Table 1. The set of Operon primers used in RAPD reactions

\begin{tabular}{|c|c|c|l|c|l|l|l|l|l|}
\hline 1 & OPA.01 & 6 & OPB.03 & 11 & OPC.03 & 16 & OPD.01 & 21 & OPE.01 \\
\hline 2 & OPA.02 & 7 & OPB.05 & 12 & OPC.08 & 17 & OPD.02 & 22 & OPE.03 \\
\hline 3 & OPA.03 & 8 & OPB.07 & 13 & OPC.09 & 18 & OPD.05 & 23 & OPE.05 \\
\hline 4 & OPA.04 & 9 & OPB.09 & 14 & OPC.12 & 19 & OPD.06 & 24 & OPF.01 \\
\hline 5 & OPA.09 & 10 & OPB.10 & 15 & OPC.19 & 20 & OPD.09 & 25 & OPF.05 \\
\hline
\end{tabular}

: Primer generates monomorphic bands

: Primer generates no bands

: Primer generates polymorphic bands

The findings of this study indicated that genetic variations may exist in in vitro culture of date palm inflorescence derived plantlets. Although plant tissue culture has been considered as a mean of vegetative propagation in which a rapid and identical (phonetically and genetically) clones are produced. Somaclonal variations in some plant species may result from changes in nuclear, mitochondrial, chloroplast genome, epigenetic variation as well. It is likely that this is a consequence of tissue culture and could have been induced in the callus production stage due to the use of high concentration of 2,4-D. In vitro production of date palm via indirect organogenesis or somatic embryogenesis require the application of relatively high concentration of 2,4-D or NAA for the initiation process $(24,25)$. However these auxin are known to be associated with genetic instability in plants $(26,27,28)$. Callus obtained from tissue culture is highly heterogeneous $(29,30)$ and it is also highly susceptible to mutational change during somatic embryogenesis (31). Frequency of variations depends on some factors: of plant genotype, type of explants, 
Saleh M. Bader ${ }^{(1)}$, Michael Baum ${ }^{(2)}$, Hussam. S. M. Khierallah ${ }^{(3)}$, \& Wafaa Choumane ${ }^{(4)}$

type of technique used, type and concentrations of growth regulators, age of callus culture or number of subcultures $(32,33)$.

These changes have been explained as the most suitable adaptation mechanism for the new environmental conditions exploiting the plasticity of the plant genome (34). The probable causes include one or more of several processes such as changes in karyotype chromosome number, structure), point mutation, somatic crossing over, sister chromatid exchange, DNA methylation, activation of transposable elements and epigenetic variations (32).
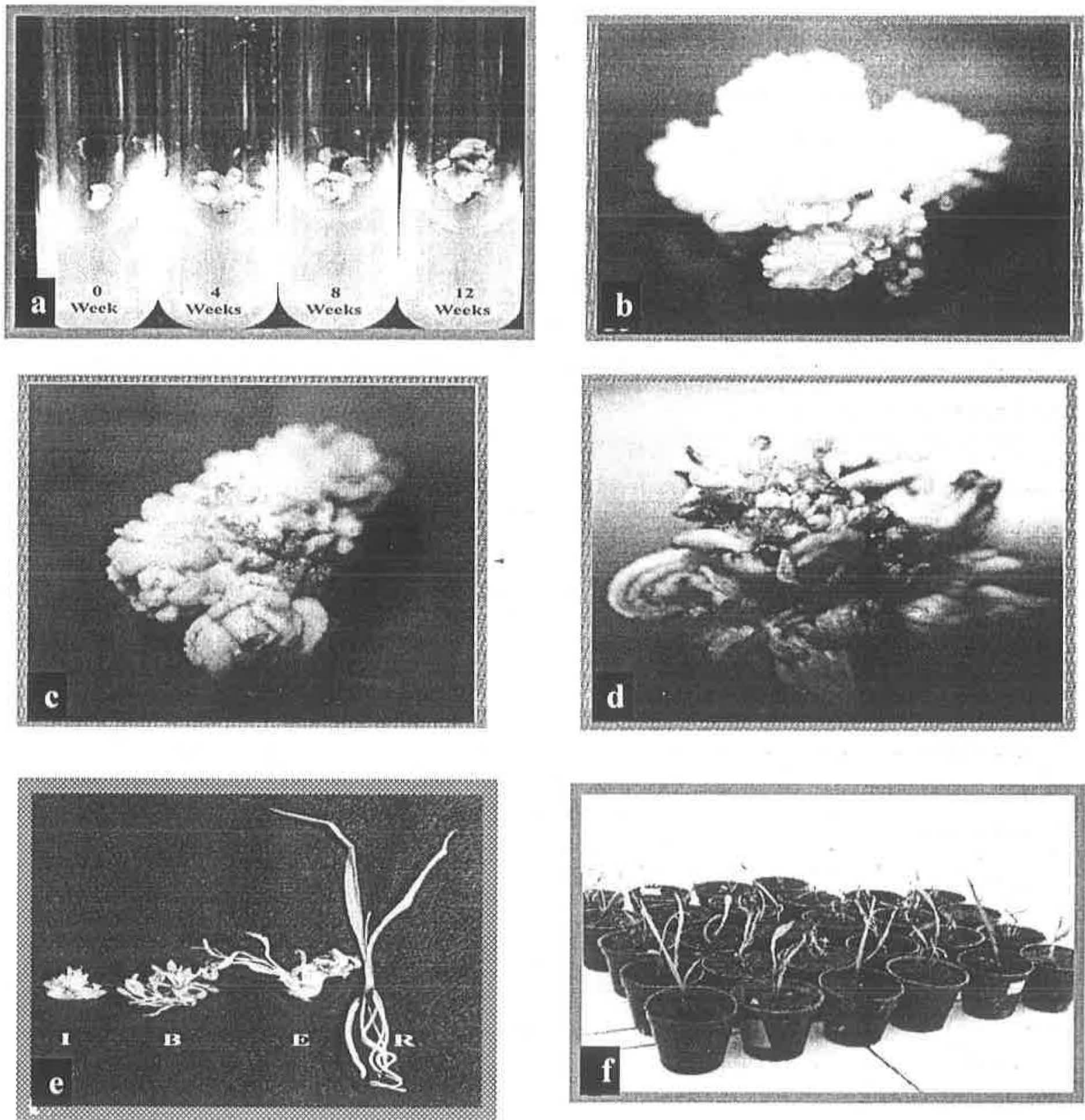

Fig. 1: In vitro Micropropagation stages of date palm using inflorescence explants a:

Callus formation after 12 weeks b,c,d: adventitious bud formation and development from callus after $0,6,12$ weeks respectively e: shoots elongation and rooting f: Plantlets acclimatization in greenhouse. 
Table 2. Polymorphisms reveled by RAPD markers using the primers (OPB.07, OPC.08 and OPD.01). (+) presence of the amplified band.(-) absence of the amplified band.

\begin{tabular}{|c|c|c|c|c|c|c|c|c|c|c|c|c|c|}
\hline \multirow{2}{*}{ Cultivars } & \multirow{2}{*}{ Primers } & \multirow{2}{*}{$\begin{array}{l}\text { MW(bp) of } \\
\text { polymorphic } \\
\text { bands }\end{array}$} & \multirow{2}{*}{$\begin{array}{l}\text { Intact } \\
\text { trees }\end{array}$} & \multicolumn{10}{|c|}{ Samples tested } \\
\hline & & & & 1 & 2 & 3 & 4 & 5 & 6 & 7 & 8 & 9 & 10 \\
\hline \multirow{5}{*}{ Maktom } & & 4300 & + & + & + & + & - & + & + & + & + & + & + \\
\hline & OPB.07 & 1600 & - & - & - & - & + & - & - & - & - & - & - \\
\hline & & 800 & - & - & - & - & + & - & - & - & - & - & - \\
\hline & & 3500 & - & - & - & - & + & - & - & - & - & - & - \\
\hline & OPC. 08 & 1200 & - & - & - & - & + & - & - & - & - & - & - \\
\hline Barhi & OPD. 01 & 1700 & - & - & - & - & - & - & - & - & - & + & - \\
\hline
\end{tabular}

Somaclonal variations can be characterized based on morphological, biochemical (isozymes) and DNA markers such as Randomly Amplified Polymorphic DNA (RAPDs), Restriction Fragment Length Polymorphism (RFLPs), Amplified Fragments Length polymorphism (AFLPs) and others (32). DNA molecular markers have been successfully used to screen date palm plants derived from tissue culture and detect genetic stability (35). RAPD technique has been reported to be useful for studying genetic variation in date palm (36) and the detection of genetic stability of tissue culture derived plants $(17,37)$.

In conclusion, in vitro micropropagation of date palm by using inflorescence explants is a promising technique for the mass production of high quality varieties. PCR-RAPD technique is a useful method for the detection of genetic stability of tissue culture derived plants at early stage. 
Saleh M. Bader ${ }^{(1)}$, Michael Baum ${ }^{(2)}$, Hussam. S. M. Khierallah ${ }^{(3)}$, \& Wafaa Choumane ${ }^{(4)}$
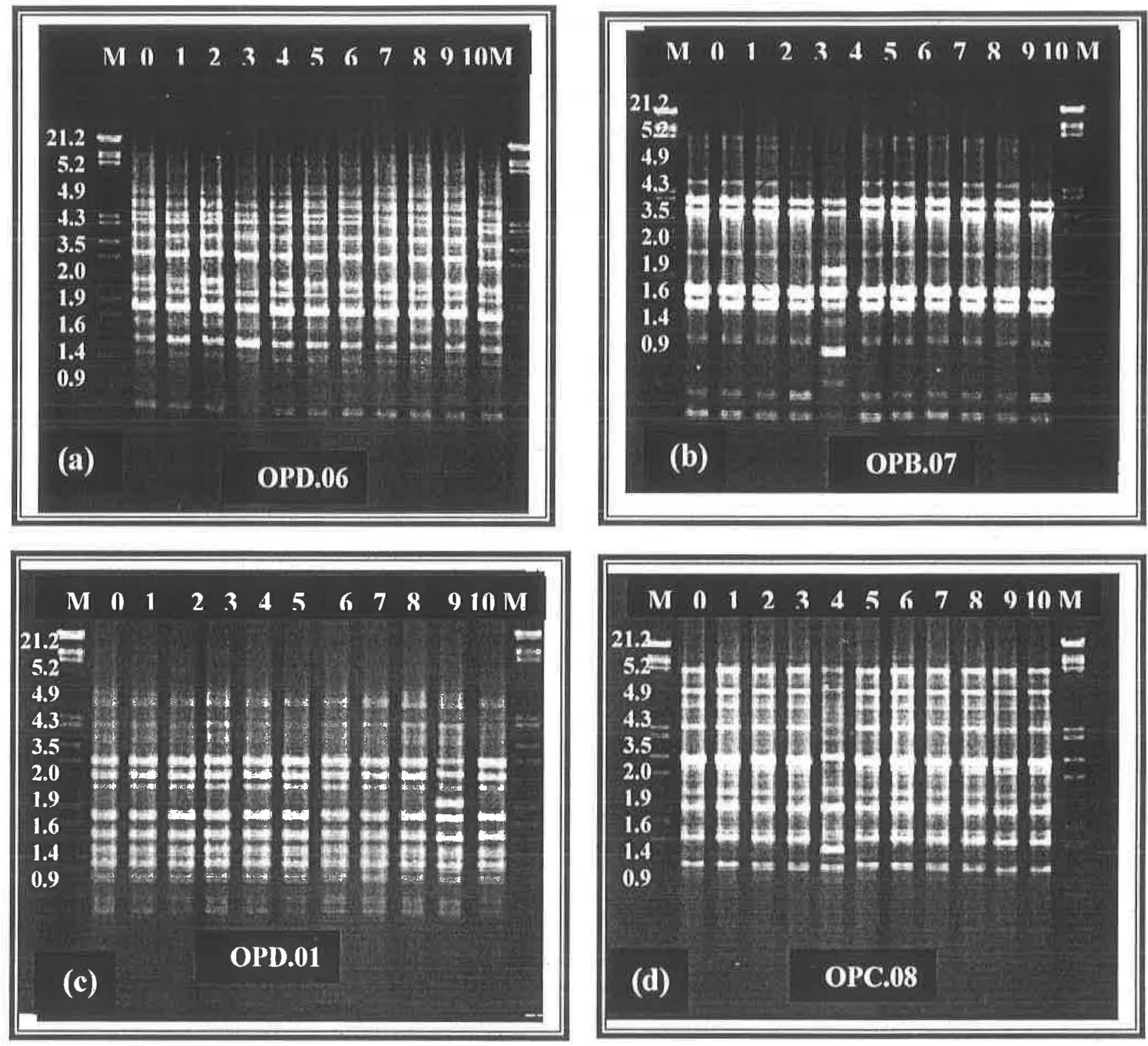

Fig. 2. (a) Monomorphic banding patterns of samples tested reveled by OPD.06 primer for Barhi, (b,c,d) polymorphic banding patterns using the primers (OPB.07, OPC.08 for Maktom and OPD.01 for Barhi), Numbers on the left indicate the fragment size of molecular weight markers (lane $\mathrm{M}$ ) in $\mathrm{kb}$. The lanes 0 are the banding pattern of the intact trees, while the lanes 1 to 10 are the banding pattern of the samples selected randomly from tissue culture derived plantlets 
REFERENCES

1. Barrow, S. Kew Bull. 53:513-575 (1998).

2. Munier, P. Fruits. 36. No 7-8: 437-450 (1981).

3. Al-Wasel, A.S.A. In: The Inter. Conf. Date Palm, Nov. Assiut Univ. Egypt. Pp. 97-106 (1999).

4. Drira, N. and A. Benbadis. J. Plant Physiol. Vol. 119. pp. 227-235 (1994).

5. Loutfi, K. and H. Chlyah. Agronomic 18: 573-580 (1998).

6. Abahmane, A. (Abst) In: Date Palm Inter. Meeting, Apr, KSA(2003)

7. Klekowski, E.J. Edinburgh. 86B:67-73 (1985).

8. Al-Wasel, A.S. Arab J. of Biotechnology. Vol 3., (2):245-265 (2000).

9. McCubbin M.J.; Zaid, A. and J. Van Staden. Emir. J. Agric. Sci. 16(1): 814 (2004).

10. Al-Kaabi, H.S.; Zaid, A. and C. Ainsworth. The International Workshop on True-To-Typeness of Date Palm Tissue Culture-Derived Plants, Morocco, 23 - 25 May, (2005).

11.Al-Mazroui, H.S; Zaid. A; and N. Bouhouche. (Abst). $3^{\text {rd }}$. Inter. Date Palm Conf, Feb, Abu-Dhabi, UAE (2006).

12. Shabana, H.R.; Al- Shiraqui, R.M.K; Mansoor, L.M. and W.M. AlSafodi. Proc. First, Inter. Conf. Date Palms, Mar., 1998, Al-Ain, UAE. Pp. 168-172 (1998).

13. Sedra, M.H., El-Filali, H., Benzine, A., Allaoui, M., Nour, S. and Boussak, Z. Fruits. 1: 247-259 (1996).

14.Bendiab, K., Baaziz, M., Brakez, Z. and Sedra, M.H Euphytica. 65: 23-32 (1993).

15.Bennaceur, M., Lanaud, C., Chevalier, M.H. and Bounagua, N. Plant Breed. 107: 56-69 (1991).

16. Gepts, P. In: Hecht MK (ed.) Evolutionary Biology. Plenum Press, New York. Vol 27 pp. 51-93 (1993).

17. Al-Khalifah, N.S. and E. Askari. In: $3^{\text {rd }}$ Inter, Date Palm, Conf, Feb, 1921. Abu-Dhabi. UAE (2006).

18. Mokhtar, T.; Abdel, A.B.; Abdel majid , R.; Andre, R and M. Mohamed.. In: Proc The First Inter. Conf. on Date Palms. Al-Ain. UAE (2006).

19. Murashige, T. and Skoog, F. Physiol. Plant. 15:473-497 (1962).

20.Benito, C; Figueiras, A.M; Zaragozal, C; Gallego, F.j. and A. Dela Penal.. Journal Plant Molecular Biology. Vol. 21 (1):181-183 (1993).

21. Sambrook, J.; Fritsch, E. F. and T . Maniatis, Molecular Cloning: A Laboratory Manual ( $2^{\text {nd }}$ end). Cold Spring Harbor. NY(1989).

22. Williams, K.J.; Kubelik, A.; Livak, K.; Rafalski, J. and S. Tingey. Nucleic acids Research, 18: 6531-6535 (1990).

23. Roch. Mlecular. Biochemicals Company. Taq DNA polymerase from Thermus aquatcus. BM. Germany.( 1999).

24. Tisserat, B. Journal Of Experimental Botany 30: 1275-1283 (1979).

25. Bhaskaran, S and R.H. Smith. Plant Cell Reports 12:22-25 (1992). 
26. Karp, A. Newsletter of the International Association of Plant Tissue Culture 58: 2-11 (1989).

27. Phillips R.L.; Kaeppler, S.M. and P. Olhoft. Proceeding Of The National Academy of Science USA. 91: 5222-5226 (1994).

28. Cullis, C.A. In: Lerner, H.R. (Ed). Plant Adaptation to Stress Environments. Marcel Dekker, New York. Pp. 149-160 (1994).

29. Reynolds, J.F. and Murashige, T. In Vitro 15:383-387.( 1979).

30. Tisserat, B and D. DeMason. Ann Bot. 46:465-472 (1980).

31. Torres, A.M and B. Tisserat. American Journal of Botany 67:162-167 (1980).

32. Brar, D.S. and S.M. Jain. In: Jain, S.M.; Barar, D.S. And B.S. Ahloowalia (Eds) Somaclonal Variation And Induced Mutation In Crop Improvement. Kluwer Academic Publishers London. UK, p 15-37 (1998).

33. Ramawat, K. G. Plant Biotechnology. Reprint of the Second Edition. S.Chand and Company. Ltd. New Delhi. India.( 2004).

34.Parfitt, D.E. and S. Arulsekar. In: Bonga, J.M. and D.J. Durzan (Eds) Cell and Tissue Culture in Forestry Volume 1. General Principles and Biotechnology, Martinus Nijhoff Publishers. Boston. USA. pp 286-297 (1987).

35. Corniquel, B. and L. Mercier. Plant Sci., 101: 163-172 (1994).

36. Sedra M.H, Las Hermes P.; Trouslot, P.; Combes, M.C.; and S. Hamon. Euphytica 103:75-82 (1998).

37. Ali, T.A.; Jubrail, J.M and A.M. Jassim. $3^{\text {rd }}$ Inter, Date Palm, Conf, Feb, 19-21, Abu-Dhabi. UAE. (2006). 